\title{
CHINA - PAKISTAN ECONOMIC CORRIDOR: CHALLENGES AND OPPORTUNITIES FOR PAKISTAN
}

\author{
*Amna Ali, Research Scholar, Department. of International Relations, Federal Urdu \\ University, Karachi- Pakistan (aamnaameer@hotmail.com) \\ ** Prof. Dr. Samar Sultana, Professor, Department of Political Science, University of \\ Karachi, Karachi - Pakistan
}

\begin{abstract}
One of the most highlighted projects of this decade is China Pakistan Economic Corridor (CPEC), between China and Pakistan this project leads its Uniqueness because both countries are different in account of social and political aspects. Despite of this Difference this paper explains about the challenges and opportunities for both countries through CPEC and also explains Pakistan's explicit issues. Both countries facing different challenges but if Pakistan wants to have equal opportunities from CPEC so it is necessary to work on some explicit issues, initially we need skilled labor, highly qualified engineer, quality education from root to top, correct political concern also evolve for future, so we can take over all important project from chines, and avail all the coastal areas of Baluchistan, it is crucial favor for Pakistan to provides equal educational opportunity for Baluchistan people. Moreover, formulate long term policy of eliminating poverty on the other hand equal distribution of national wealth and atelic group of Pakistan, work for restoration confident of urban Sindh and Baluchistan people.
\end{abstract}

KEYWORDS: China-Pakistan Economic corridor (CPEC), opportunities, challenges, Explicit Issues of Pakistan.

\section{INTRODUCTION}

World witness the close friendship between Pakistan and China, and CPEC took off their friendship strategic and economic partnership to a new height, both countries are working together on CPEC for betterment. 
China is already economical strong country depends on manufacture and export, having a quality education system, skilled labor also well qualified professionals in all fields on the other hand Pakistan is in less develop countries and economy based on agricultural, and also both countries have different culture, language and customs despite of these differences Pakistan-china relation is the best example in international relation, due to this much strong bond these countries suffer from many problems, also CPEC facing a great criticism from all over the world many of experts explains CPEC in a favor of china and some prove it's in Pakistan favor. (News ABC, 2016)

For a purpose of understand CPEC, it is more important to understand Gwadar port too.

I. Introduction of CPEC: it has a long route of 3,218 kilometer, in next few years it will be on map, highways, railways and pipelines to be built in CPEC.

II. II. Cost of CPEC: The surveyed cost of the undertaking would be US $\$ 75$ billion, out of which US\$45 now under billion will ensure that the path winds up operational by 2020. The straggling remains of the Investment will be spent on essentialness age and structure development. (Javaid, \& Jahangir, 2015)

III. Stages of CPEC: The CPEC wind has been withdrawn into stages, the principal arrange being the fulfillment of Gwadar International Airport and true-blue updates of Gwadar Port. This stage is depended on to be done by the year 2017. The errand correspondingly consolidates the improvement of Karakoram Highway-the road that interfaces China with Pakistan and state of fiber-optic line ensuring better correspondence between the two countries.

IV. Gwadar Port: Gwadar port is the major part of CPEC and has great worth, it would be a game changer for Pakistan and also strengthen the international economy because of its location, capacity and in a comparison of other ports.

V. Importance of Gwadar in CPEC: Sea course for oil supply to the china through Strait of Malacca is around 12,000 km long, while the partition from Gwadar port to China region Xingjian is about $3,000 \mathrm{~km}$, and besides $3,500 \mathrm{~km}$ from Xingjian to eastern float of China. (Kiani, 2007) 
VI. Location of Gwadar Port: Gwadar port is the remote sea port, organized at the gateway of the Gulf of Persia practically 234 nautical miles of Karachi in the west and around 390 nautical miles east of the Hormuz Strait. Just $80 \mathrm{~km}$ far from the periphery of Iran, from Oman Cape al-Hadd it is around 320 $\mathrm{km}$ and organized in closeness to the Chabahar and Bander Abbas ports of Iran, beside the unstable district of Hormuz Strait which is the central course for overall oil supplies in the zone. Zone of Gwadar port illuminates its incentive in CPEC. (Kabraji, 2012)

If we compare Gwadar port with other ports here we can see some huge differences, in account of depth of sea port and number of berths.

\begin{tabular}{|lcc|}
\hline $\begin{array}{l}\text { Ports Name } \\
\text { Berths }\end{array}$ & Depth of Seaport & No of \\
\hline Bandar Abbas (Iran) & $9.4 \mathrm{M}-10 \mathrm{M}$ & 24 \\
\hline Chahbahar (Iran) & $11 \mathrm{M}$ & 10 \\
\hline Damman (Saudi Arabia) & $9 \mathrm{M}$ & 39 \\
\hline Doha (Qatar) & $11.2 \mathrm{M}-12 \mathrm{M}$ & 29 \\
\hline Gwadar Port (Pakistan) & $17.1 \mathrm{M}-18.2 \mathrm{M}$ & 120 \\
\hline Jebel Ali (UAE) & $15.5 \mathrm{M}-16 \mathrm{M}$ & 67 \\
\hline Karachi (Pakistan) & $9.4 \mathrm{M}-10 \mathrm{M}$ & 33 \\
\hline Khor Fakkan (UAE) & $16 \mathrm{M}$ & 20 \\
\hline Salalah (Oman) & $10 \mathrm{M}$ & 19 \\
\hline
\end{tabular}

As per above table it is easy to compare Gwadar Port with other ports.

\section{CPEC AND ITS CHALLENGES}

CPEC joins China direct with the Indian Ocean and Middle East region of the significant port of Gwadar, diminishing its ebb and flow dependence on South China, as the last transforms into a flawed space between a different neighborhood and worldwide on-screen characters and can be squashed each time the forceful power in the Asia-Pacific territory. China is after a short time transmitting $80 \%$ of its oil and centrality needs through Malacca weight and continuously feels it's money related and criticalness security essentialness for the zone is under good old-fashioned dangers in light of the hoisting of weights among China and the zone and general players in the South and the East China Sea. (Limao, \& Venables, 


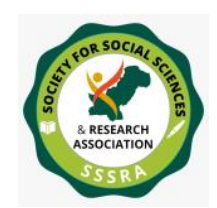

Pak. Journal of Int'L Affairs, Vol 1, Issue 2 (2018)

China - Pakistan Economic,...

2001) Thus, China is searching for elective sensible travel courses both fiscally and safely; CPEC is the best choice for China that interfaces it particularly with the Indian Ocean through Gwadar Port. Furthermore, another side of the photograph addresses Pakistan.

As displayed by geopolitical Pakistan is the friendliest moneyrelated way for trade and travel sharpens that draw in access to Central Asia, South Asia, East Asia and Western Asia. His part remained central in the midst of the cold war and the post-new war's an eventual outcome of his geostrategic region and neighbors to the making economies of the zone, especially China and India. It can go about as a fundamental cash related geology for ordinary trade. Regardless, "Pakistan disregard to get a handle on the money related the mind-blowing position of its key locale and geography in the domain". (Little 2006)

The current shared trade volume between China and Pakistan is essentially low. CPEC, if associated with India, will other than creating trade between China, India, and Pakistan. India's wire in the CPEC will other than help normal trade between China and India higher than at whatever point in late memory. The CPEC, which experiences the zones of China and Pakistan maintaining a strategic distance from on various countries, could make the countries of Central Asia, Afghanistan, Western Asia and India. The landlocked and resource-rich countries in Central Asia have reliably fortified access to normal marketplaces, including China, India, Pakistan, and other states of Western Asia. Both Tajikistan and Afghanistan have travel understandings; CPEC will empower them to transport their stock and to put them more intensely on the adjoining and general markets, associating with standard money related and trade joints. (Haider, 2007)

Furthermore, CPEC is a power that brings investment, develops infrastructure and rises GDP in Pakistan, the project facing many of difficulties. In fact, many of voices rise in Pakistan and expressed their fears about CPEC, Fear to be takeover by china, because as a matter of fact Pakistan have no comparison with china in any manner while engineer's, workers and labor working on CPEC are well trained and qualified and Pakistan have no match with them. It's a need of time for Pakistan to train their people to work with Chinese so it would be convenient for Pakistan in near future. As appeared by records, Pakistan educational ratio decreased to $58 \%$ from $60 \%$, exposed the Economic Survey of Pakistan (2016-2017), diminishing getting ready rate can make 
some standard issues. (Bhattacharjee, 2015) Furthermore, Pakistan defying some inside strings as for CPEC, clear demand Baluchistan's, security issues the degree that commonplace security could be the best issue for the CPEC, as it encounters an area of the areas standing up to the best security challenges. The best test for the CPEC is the commonplace safety condition.

\section{CPEC AND ITS OPPORTUNITES}

Typically, China and Pakistan have collaborated nearly on the key and political stages. Specifically, the 2 nations are endeavoring tries to make essential their two-sided made effort monetarily as appropriately. the change of the China-Pakistan Economic Corridor (CPEC) is an opinion of view which shows the interchange. At its center, the CPEC is a vital measure development to construct quality, street, and harbor to make fiscal relationship among Pakistan and China. The development has been reasonably gotten in the two countries, notwithstanding how it isn't overall without its issues. In the end, China and Pakistan see the CPEC as a fresh out of the plastic new wellspring of farthest point participation among there. Particular countrywide progress systems, which may in like way enable the 2 general zones to unwind their nearby by political facilitated exertion into multifaceted, cash related participation, get shared rewards and achieve win-win happens. (Naseem, 2015) For the budgetary segment to attain its capacity, in any case, there are safety and dogmatic requesting conditions in Pakistan that must be have a habit of to.

Meanwhile, China considers this change attempts the farthest point supply of value and achievement for each overall region. From a Chinese language point of view, collaboration inside the locales of security and cash related edges are purposefully bound, and changes in a single segment can overhaul the inverse. it's miles nearly as paying little respect to the way that thriving and budgetary points of view are two separate wheels on a similar auto, and both need to swing to transport things ahead. China recognizes cash related change can bolster Pakistan's inner security, in this way reviving the last's budgetary structure by techniques for energy for foundation expands in spite of the difference in oil and gas pipelines. China trusts this may make a specific time of value inside Pakistan and in flip balance China's western edges, especially the area of Xinjiang. (Qazi, 2007) 
Pakistan likewise basically values the budgetary anteroom and points of view it as everything considered gainful to the degree legitimate issues and money related movement. This procedure is that fundamentally enhancing Pakistan's budgetary framework. Pakistan's inside security and modify paying little personality to the way that Pakistan has worked genuinely to strike at non-standard radicalism and fear-based oppressor works out, its issues with mental battling have now not incredibly advanced in current years. Since the CPEC is so essential to the Pakistani specialists, those assignments creation districts and arranging workforce may bend up revolves around heavenly notwithstanding follower fans. In reality, Pakistani pros, by then, have guaranteed China they'll do the entire thing done to ensure the affirmation of Chinese individuals. (Godement, 2014) This is a plausible obligation inside the short navigate time to traverse. in any case, as the years propelled, it winds up being more incredible for Pakistan to ensure the security of the CPEC's making transportation structures, while in the movement to require expanding speculations of thriving staff and surface help.

CPEC will make ready to address Pakistan with immense open duty approaches and physically associate China with Asia, Europe and previous business elements. Fundamentally, $80 \%$ of Chinese oil is transported from the Strait of Malacca to Shanghai (the hole is just 16,000 $\mathrm{km}$ and endures 2-3 months), with Gwadar having the chance to work, the fragment will fall underneath 5,000. km. 21 Energy forces, including controlled vitality for vitality, gas, coal and sunlight based vitality, can supply up to 10,400 megawatts (MW) before March 14, 2018, against the likelihood that everything will work appropriately. As China Daily brings up, these exercises will progress through a centrality of 16,400 MW. (Naseem, 2015)

As a feature of the $\$ 11$ million fundamental work between the urban areas of Karachi and Lahore, along $1100 \mathrm{~km}$ interstate is being manufactured, which will be totally remodelled amongst Rawalpindi and Karakoram Road and restored. The railroad line that enters Karachi-Peshawar will act as though it were going to movement dependably for 160 kilometres by December 2019. The Pakistani railroad framework will be extended to at last associate China with the South Sincan rail route to Kashgar. A consolidated fuel and gas transportation pipeline design is utilized as a feature of the organization, which incorporates a $\$ 2.5$ billion gas pipeline from Iran amongst Gwadar and Nawab Shah. (Xu, 2015) 
CPEC will make ready to address Pakistan with colossal open duty approaches and physically interface China with Asia, Europe and previous business elements. Essentially, $80 \%$ of Chinese oil is transported from the Strait of Malacca to Shanghai (the hole is just 16,000 km and keeps going 2-3 months), with Gwadar having the chance to work, the fragment will fall underneath $5,000 \mathrm{~km} .21$ Energy forces, including controlled vitality for vitality, gas, coal and sun-powered vitality, can supply up to 10,400 megawatts (MW) before March 14, 2018, against the likelihood that everything will work legitimately. As China Daily calls attention to, these exercises will progress through a centrality of 16,400 MW. (Godement, 2014)

As a major aspect of the $\$ 11$ million fundamental work between the urban communities of Karachi and Lahore, along $1100 \mathrm{~km}$ interstate is being fabricated, which will be totally revamped amongst Rawalpindi and Karakoram Road and reestablished. The railroad line that enters KarachiPeshawar will carry on as though it were going to movement dependably for 160 kilometers by December 2019. The Pakistani railroad framework will be extended to at long last interface China with the South Sincan rail route to Kashgar. A joined fuel and gas transportation pipeline design is utilized as a major aspect of the organization, which incorporates a $\$ 2.5$ billion gas pipeline from Iran amongst Gwadar and Nawab Shah. (Shah, 2015)

Middle Eastern oil was poured into Gwadar and transported to China, allowing a journey of $12,000 \mathrm{~km}$ to $2,395 \mathrm{~km}$. The new road of maritime silk continues as a step forward that is part of Eurasia three billion people in Asia, Africa and Europe. When the mobilization in full swing by the complexity of Gwadar's budget in Pakistan and Afghanistan, Uzbekistan, a collaborator of Sri Lanka, by the Central Asian countries, including Iran and Xinjiang, a segment is understanding the expedition. \$ 33 billion voluntary assistance from private consortia to support a myriad of ongoing factual problems in Pakistan over $€ 4$ million, of which eight are continuous and regular, from $2 \%$ to $2.5 \%$ of GDP annual decline in Pakistan. 9 Sources are the most important part of the monitoring period at CPEC Mender, an income source of \$ 33 billion for winds in the central regions. As part of the updated "Early Harvest" meander, a limit of over 10,400 MW will be applied in 2018 and 2020. (Shah, 2015)

CPEC is awesome business suggestion, however it needs players, the players that will trade, the players that will import, and the players that 
will go about as commission specialists. Sooner than later when the task nears finishing, we will see exceptional monetary zones being made and various players opening their distribution centers and workplaces.

So, if CPEC is executed, it will profit Pakistan, however Pakistan should take a couple of hard political choices, it has time till the venture is finished, as once the thruway is prepared, it can't give it a chance to be for utilization of just China's vital significance, a significant part of the practicality of the undertaking depends if India would utilize the parkway for two way exchange, and disunity amongst India and Pakistan could make the task a non-starter.

\section{EXPLICIT ISSUES OF PAKISTAN}

\section{SERIOUS SECURITIES ISSUES}

Past to present Pakistan targeted by terrorism, all kind of terrorism example present in all over Pakistan, suicide bombing to APS attack there are a lot of examples can be seen, in this situation CPEC needs more security, because due to CPEC neighbor country is disturb from the future of Pakistan and trying hard to prove as an unsafe country by planting some agents to spread terror activities, a recent example is kulbhushan Yadav who arrested during counter intelligence operation in Baluchistan on 3 march 2016, he confess himself as an agent of India's external intelligence agency RAW, and planted in Pakistan for terrorist activities and making special efforts for the separation of Baluchistan, now time to be more careful about security not only on border but within country too. Because may be there are more Kulbhushan Yadav who are still working against Pakistan and may be they are succeeding in their mission.

Pakistan need to alliance with more countries in south Asia region for maintaining peace. In international relations there is no permanent relation between countries either its friend or enemy although relation only based on national interest, so Pakistan should focus on its national interest. Focusing on only single alliance in whole world not a good idea for any country and Pakistan already an under develop country, for the betterment and also avoiding security issues it's better to alliance with more countries.

\section{NEEDS TO UPGRDE QUALITY EDUCATION SYSTEM}


In the midst of this period, progress in advancement and preparing expect a key part in the change of a nation and country. The direction is basic for children and adolescents since Pakistan is a rising country. Under Article 25 (A) (Education) of the Pakistani Constitution, the State can guarantee to all generations from six to sixteen a free and binding path, as established by law, but unfortunately, according to ASER, the situation for preparation of the annual report. In 2016, $19 \%$ accounted for $19-16 \%$ of the school and the remaining $81 \%$ of teenagers between 6 and 16 years had not yet been prepared. The seventh ASER Survey report continuously - moved to Islamabad on Wednesday, second August 2017.with this situation of guideline structure it will be troublesome for Pakistan to be in race of change, in Pakistan, in light of lack of regard and broken imaginative and farsighted of coordinators in dynamic governments, the science and time quarter advance toward getting to be not the scarcest piece given the reputation required to reasonably use it as a supporter of countrywide and cash related impact. In light of little financing gave strategies for the masters, our R\& D establishments couldn't make any solid examinations. (Small, 2015) Lack of true blue concentrations and surroundings for inspects inside the schools and studies associations incited a rot in the extraordinary of a better direction to the volume that these days our schools have been dispatched to the omnipresence of low-degree colleges in which finest school cash related structure hyperlinks are absolutely insufficient. To take good conditions from CPEC Pakistan should base on the change in preparing so they may convey capable field experts, specialist's will's character prepared to work with chines and can manage some basic ventures in CPEC, a quality direction can settle an expansive number of thing. Pakistan's economy will fall well ordered and Education system and structure won't be totally made unless the idea of the direction system is more lamentable. (Vandewalle, (2015)

\section{ECONOMIC FLUCTUTION}

Pakistan from outrageous 3 to 4 decades is uncertain in light of war and fear condition that is the reason the money related system has a stunning impact. The lawmaking body did not profit related structure procedure to upgrade their rate sort out and various issue to decide. Forcefully evaluated instability, essentialness crises, high joblessness, low tolls, low outside exchange spares, low-wage degree and other social, monetary and political issues. These sorts of issues straightforwardly influence business works out. In the occasion that examined past the state 
issues the rate shakiness and the example of gross private amassing in Pakistan then extraordinarily difference long. Pakistan's opportunity in 1947 and money related situation was incredibly shaky, joblessness, the nonappearance of establishment and other social and budgetary bothers. (Bengali, 2015) In 1947 to 1952 ordinary rate of improvement was 3 percent in Pakistan. In 1960 development rate wound up 1.64 percent and in an addition of GDP 5.8 percent. In spite of the way that, it systematically expert monetarily well structure. All through 1965, the Pakistan and India war over Kashmir likewise impact the economy. In 1970 example end up level with about. The development of GDP changed into lessening 11.3 percent in light of division East Pakistan in 1971, nevertheless, the swelling charges 4.7 rate stays same, predictable. In 1973 GDP improvement rate 7.06 percent changed into five rates reducing, and extension cost changed into increase twofold digits 23.1 percent in light of the way that Bhutto nationalized the private quarter and hypothesis nearest 15 percent for the private region. In 1980's, Zia - ul - Haq supportted of privatization advanced toward getting to be refined constantly and the extended cost of GDP wound up 10.2 rates and extension cost was 11.9 percent. Extraordinary governments and picked administrators all through 1988-99. High esteem goes inadequacy in 1992-9 then general money related store (IMF) offers the home advance to diminished defend utilizations, moved evaluate game plan frameworks and extension rate went among 9.1 percent to 12.4 percent exorbitant rate of swelling, raised the rate insecurity and low budgetary improvement. (Jain, 1981) In 1997 s, sustenance and non-support thing are impacted by high extended extension cost 11.6 percent and 10.3 percent. In 2001 after 9-11 event, fiscally circumstance of the overall extremely balanced improvement rate of GDP, charge degree, and extension wound up affected. In 2005-06 swelling and advancement of GDP end up ordinary. Remaining year's extreme extension float in Pakistan and poor impact on cash related improvement. With this history Pakistan faces an extensive number of frustrations it's an extraordinary chance to make some whole deal prepare for the security of budgetary improvement. (Hoi, 1999)

\section{LACK OF MODERN TECHNOLOGIES}

According to Global Innovative Index's report-2017 Pakistan was ranked at 113 out of 127 countries. The 21 st century is the era of technology, so Pakistani authorities and policymakers can't forget about its interplay with entrepreneurship and can't seek attention totally on "motorways and metro buses" — without the feasible use of technology 
they even cannot survive. The government of Pakistan ought to grow sponsoring for R\&D from an irrelevant per capita to satisfactory per capita. Lack of sufficient funds led to "mental drainage" and many experts opted for better payments abroad, others went to school. Experts have reported that some $\mathrm{R} \& \mathrm{D}$ departments will not survive unless they are funded. Pakistan and other countries in the case of the country's R \& D funding, Pakistan's GDP has been reduced to only $0.29 \% \mathrm{R} \& \mathrm{D}$, undoubtedly $0.82 \%$ of GDP in India, Turkey is being distributed $0.94 \%$, $1.13 \%$ of Malaysia and $1.15 \%$ of Brazil and countries with the largest number of sponsors. Research and development are $4.21 \%$ of Israeli GDP, $4.15 \%$ in South Korea and $3.47 \%$ in Japan. (Vaughn, \& Morrison, 2006)

\section{ELEMINATION OF POVERTY}

Poverty is a terrible problem in the construction scene in general. Pakistan is home to innumerable encounters in absurd poverty. The destruction in Pakistan is over, but there is still much to be done. Multidimensional Poverty Index (WPI), the Pakistani government is preparing legislation in June 2016 and the report on the method of transformation and change, says that 39 percent of Pakistanis live in multidimensional dejection. UNDP and Oxford poverty and developed in 2010 from the process of MPI human development initiative, although responsible people and wealth assets used with the challenges associated with managing and life style greater despair. Raporda reported that the cost of national impotence in Pakistan fell 39-50 percent between 2004 and 2015. (Wang, 2015) This is a generous refusal; No matter what happens, all the changes between the different regions of the United States are irregular. The desperation in urban areas is 9.3 percent when it reaches 54.6 percent in natural cities. Furthermore, the surprising irregularities in each region are managed legally internally (FATA) and are recorded at the best cost in Balochistan. MPI reports "FATA (73 percent) and Balochistan (71 percent) Khyber over a third remaining multi-dimensional dejection percentage and forty-nine in Pakhtunkhwa, Gilgit Baltistan and 43 percent of Sind, reports of one hundred Punjab 31. and Azad Jammu and Kashmir come out of poverty over $90 \%$ with 25 "also Qilla Abdullah in Balochistan Harnai and Barkham bring together more regions, Islamabad, Karachi and Lahore. Here, more than $10 \%$ of the local population seems to live in multidimensional poverty. The relationship and the decline of the multidimensional dejection in Baluchistan, as the slowest in the early stages of 
its destruction in the Sindh region in a decade seemed to have no doubts. (Xu, 2015)

\section{CONCLUSION}

CPEC is one of the corridor of the mighty project of one belt one road and Pakistan is the part of this project, as per my research CPEC is not going to boost Pakistan economic condition now not even after years, because this is an agricultural based country for competing with other countries Pakistan needs to focus on technology education, because CPEC will not provide better education system or advance technology. In CPEC Pakistan is just a facilitator who is providing a path to china for building their economy, when rest of countries working in space Pakistan still surviving for develop roads and railways, to make certain Pakistan have awesome specialist yet the nonattendance of financing structure government makes them demotivated for headway, the assembly should reinforce inventive work in extraordinary endeavors that are associated with comes about like imaginative work sponsoring ought to be a rising, on account of the truth $R \& D$ expenditure is a vital pointer of a forceful impact of this fiscal system. Most of Pakistan's budget goes to its nuclear program, military and fighting terrorism spending too much budget in defense sector is not in favor of Pakistan's development even after spending too much in defense sector Pakistan still targeted by terrorism. The day Pakistan gives up its military policy Pakistan will grow rapidly and has the potential to become an economic hub like Singapore or UAE, also Pakistan need to concentrate on Baluchistan and bring justice to its people for maintain peace with in country, need to spend some more on education and IT technology to compete with other countries and must have a more active foreign policy and ask foreign companies to invest in Pakistan. Explicit issues are rising day by day in Pakistan so it's a need of time to focus on them and find permanent solution, poverty and lack of educations are major issues, if Pakistan wants to avail same opportunities from CPEC so it is necessary to work on some explicit issues, own skilled labor who work in CPEC with chines, highly qualified engineer, quality education from root to top, correct political concern and long term policies, so we can be a part of all important project with chines, and avail all the coastal areas of Baluchistan, it will be in Pakistan favor to provides equal educational opportunity for Baluchistan people. Also formulate policy for eliminating poverty on the other hand equal distribution of national wealth and atelic group of Pakistan, work for restoration confident of urban Sindh and Baluchistan people 


\section{REFERENCES}

Bengali, K. (2015) China-Pakistan Economic Corridor and Route Controversy. [online] Chief Minister Policy Reform Unit, Government of Balochistan. Available at: http://cmpru.gob.pk/reports/CPEC.pdf [Accessed 28 Jan. 2016].

Bhattacharjee, D. (2015) China Pakistan Economic Corridor. SSRN Electronic Journal.

Godement, F. (2014) China's Neighbourhood Policy. European Council on Foreign Relations, Asia Centre, China Analysis.

Haider, S. F. (2007) Pakistan Port Opens New Possibilities [online Available from:

http://www.atimes.com/atimes/South_Asia/IC22Df02.html

Hoi, C. T. (1999) How will feeder operators view the creation of secondary hubs: Will it give rise to co-operation of competition? In Proceedings of the 21st World Port Conference, 15-21 May 1999. The International Association of Ports and Harbors, Tokyo

Jain, R. (1981) China South Asian relations, 1947-1980. New Delhi: Radiant.

Javaid, U. and Jahangir, A. (2015) 'Pakistan-China Strategic Relationship: A Glorious Journey of 55 Years', JRSP, 52(01), pp.157-183.

Kabraji, R. (2012) The China-Pakistan Alliance: Rhetoric and Limitations. Chatham House Asia Programme.

Kiani, K. (2007) \$60bn Income likely from Mega Projects. [Online] Available from: http://www.dawn.com/news/273091/60bnincome- likelyfrom-mega-projects

Limao, N., \& Venables, A. J. (2001) Infrastructure, geographical disadvantage, transport costs, and trade. The World Bank Economic Review. 15(3). pp. 451-479. 
Little A. D. (2006) Analysis for preparation of Gwadar Port Master Plan. Musharraf's Address at SCO Summit held at Shanghai, China (2006).

[Online] Available from:

https://presidentmusharraf.wordpress.com/2006/07/07/sco-statessummit2006/

Naseem, A. (2015) Impact of China Pak Economic Corridor - A Bird's Eye View. [online] Islamabad: BMA Capital. Available at: http://investorguide360.com/ wp-content/uploads/2015/05/Impact-ofChina-Pak-Economic-Corridor_-A-Birds-Eye-View.pdf [Accessed 28 Jan. 2016].

News ABC, (2016) Chinese President Xi Jinping tours Middle East, inks deals worth billions in bid for influence. [online] Available at: http:// www.abc.net.au/news/2016-01-22/china-president-visits-middle-east-inksdeals-worth-billions/7106292 [Accessed 28 Jan. 2016].

Qazi, A. (2007) Pakistan in Starr, S. F. The New Silk Roads: Transport and Trade in Greater Central Asia. Johns Hopkins University Press.

Shah, S. (2015) 'China"s Xi Jinping Launches Investment Deal in Pakistan', The Wall Street Journal, [Online]. Available at: http://www.wsj.com/articles/ chinas-xi-jinping-set-to-launch-investmentdeal-in-pakistan-1429533767

Small, A. (2015) China-Pakistan: A Strategic Relationship in the Shadows. [Blog] Yale Global Online. Available at: http://yaleglobal.yale.edu/content/chinapakistan-strategic-relationsshadows [Accessed 28 Jan. 2016].

Vandewalle, L. (2015) 'In-depth Analysis Pakistan and China: 'Iron Brothers' Forever?', Policy department European Parliament, [online] 549(052). Available at: http://www.europarl.europa.eu/RegData/etudes/IDAN/2015/549052/EXP O_IDA(2015)549052_EN.pdf [Accessed 24 Jan. 2016].

Vaughn, B. and Morrison, W. (2006) China-Southeast Asia Relations: Trends, Issues, and Implications for the United States. Congressional Research Service , The Library of Congress. 
Wang, J. (2015) 'China's 'New Silk road': A case study in Eu-China relations. In: Amighini, A. \& Berkofsky, A. ed', Xi's Policy Gambles: The Bumpy Road Ahead (pp. 92-109). Beijing: ISPI.

$\mathrm{Xu}$, S. (2015) 'Vision and Actions on Jointly Building Silk Road Economic Belt and 21st-Century Maritime Silk Road', National Development and Reform Commission, Ministry of Foreign Affairs, and Ministry of Commerce of the People's Republic of China, with State Council authorization, (2015). [online] Available at: http://en.ndrc.gov.cn/newsrelease/201503/t20150330_669367.html [Accessed 22 Nov. 2015]. 